Brues $^{3}$ but later were found to agree with Mayr's description of $T$. dalmani. The type of $T$. fiskei agrees with the description and when compared with specimens of $T$. dalmani was found to be the same. Prof. C. T. Brues, who has gone over the description and compared the specimens, is also of the opinion that $T$. fiskei and $T$. dalmani are the same species.

This species has been taken in Maine, New Hampshire, Massachusetts, New York, Ottawa, Canada, England, Holland and Germany. It has been reared from the eggs of Notolophus antiqua and Hemerocampa leucostigma in U. S. Crawford records this species as having been reared from the eggs of Orgyia antiqua in England, Holland and Ottawa, Canada.

Telenomus abnormis Crawford.

Proc. U. S. Nat. Mus., vol. 41, p. 270 (1911).

I have not seen this species. It is described as having the second segment about as long as wide. It differs in this character from any other species under consideration in this paper.

The females in this group may be separated with the following table:

1. Antennal club five-jointed. . . . . . . . . . . . . . . . . 3

Antennal club four-jointed . . . . . . . . . . . . . . .

2. Second segment of abdomen about as long as wide

abnormis, Craw.

Second segment of abdomen much longer than wide euproctidis sp. nov.

3. Abdomen truncate at apex.............dalmani (Ratz.)

Abdomen pointed at apex..........hemerocampa sp. nov.

\title{
THE NOCTUID GENUS COPABLEPHARON (HARVEY) WITH NOTES ON ITS TAXONOMIC RELATIONSHIPS.
}

By E. H. Strickland, Entomological Branch, Ottawa, Canada.

The Genus Copablepharon was erected by Harvey ('78) for a single Californian species, absidum Harv. which he had previously ('74) placed in the genus Ablepharon-Arsilonche. In his descrip- 
tion he states that the genus is related to Arsilonche in that the eyes are lashless and naked, and to Ommatostola in the ornamentations and habits of the moth. It differs from either, however, in the possession of spinose tibiæ. Both of these supposedly related genera have been placed in the sub-family Acronyctinæ by Hampson ('16).

Four species of moths were included in this genus when Smith published his list of American Lepidoptera in 1903, and he placed it next to the genus Nycterophæta, in the cuculliid group of the undivided family "Noctuidæ." This allocation of Copablepharon was accepted, with slight modifications, by taxonomists until Hampson ('03) transferred it to the sub-family Agrotinæ on account of its spined tibiæ. Barnes and McDunnough ('17) follow Hampson's classification in their check list, and this is the generally accepted standard for American Lepidopterists.

The six species now included in Copablepharon are apparently confined in their distribution to Western America. They are nowhere very common, and nothing has been published upon the immature stages of any species.

In the spring of 1913 larvæ of C. longipennis Grt. and C. grandis Strk. were taken in Manitoba and Alberta respectively. Mr. N. Criddle, who found the longipennis larvæ, and bred from them a single adult, states that the larvæ were typical "cutworms." Unfortunately Mr. Criddle did not examine the pupal stage, which was passed in an earthen cell below ground.

On May 9 a single larva of $C$. grandis was taken in a stubble field at Monarch, Alberta.

This larva resembled superficially a lightly pigmented specimen of Euxoa ochrogaster Gn. (The Red-Backed Cutworm). Grandis, however, differs from ochrogaster in that the median and lateral lines are white instead of brown. In all of the larvæ of Euxoa, and of closely related genera, that we have examined tubercle II is considerably larger than tubercle I (see diagram). In the larva of grandis, and also in specimens, now inflated, which Mr. Criddle collected at the same time as, and believes to be identical with, the specimen from which he bred longipennis this tubercle is no larger than is tubercle I.

The larva of grandis evidently hibernates when about half grown since the specimen taken on May 9 in Alberta was in the fourth 
stage. This larva was found below ground, among other cutworms, and in captivity it fed freely on alfalfa and to some extent on barley.

When mature the larva measured $1 \frac{1}{2}$ inches in length, and by July 5 it had pupated in an earthen cell similar in construction and size to that of the species of Euxoa, though it was somewhat distorted internally.

Thus it will be seen that Copablepharon larvæ are typically Agrotine in their habits, and were it not for the minute tubercle II their structure also would be in harmony with that of typical members of this sub-family.

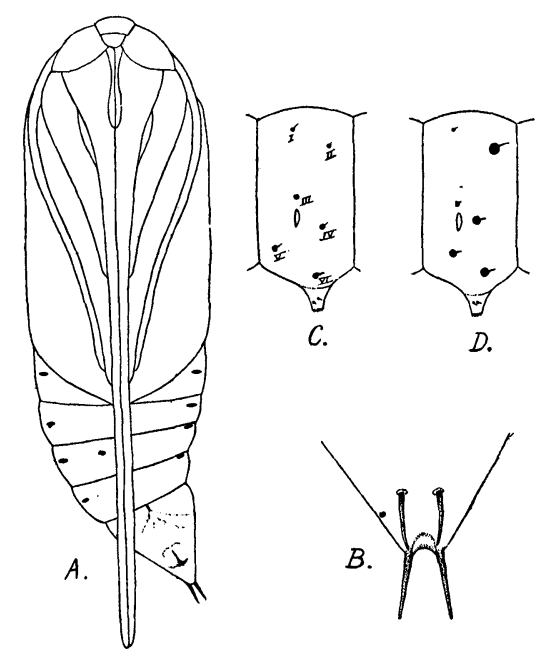

Fig. 1. A. Pupa of C. grandis, x 3;B. Cremaster of pupa, dorsal aspect, $x$ 12; $C$. Diagram of larval tubercles based on abdominal segment IV of $C$. grandis; D. Diagram of larval tubercles of typical Euxoa species based on abdominal segment IV of Chorizagrotis thanatologia Dyar.

The pupa, of which an illustration is given, is remarkable in that the proboscis sheath is so elongated that it extends beyond the apex of the abdomen. The pupa itself is $19 \mathrm{~mm}$. long and the proboscis sheath, of which $8 \mathrm{~mm}$. is free, extends $2 \mathrm{~mm}$. beyond the cremaster.

The only other Noctuid pupæ which we know to have an extended proboscis sheath are those of certain genera of the Cuculliinæ, and to a less extent the Plusiinæ. 
Mosher ('16) in her classification of Lepidopterous pupæ states that in the Cuculliinæ the wings and maxillæ (proboscis sheath) never extend beyond the caudal margin of the fourth abdominal segment. This statement is apparently based entirely upon observations made on two specimens of the same genus, Graptolitha Hbn. Humphreys ('43) figures the pupæ of several British species of the genus Cucullia in all of which the proboscis is extended well beyond segment IV. Lintner ('69), in describing the pupa of the American species Cucullia intermedia Say, states that the free end of the tongue case projects $5 / 100$ inch beyond the wing cases, and the pupa is $7 / 10$ inch long. We have examined empty pupa-cases of this species which confirm this statement and indicate that in the living pupa the free apex of the proboscis sheath extends beyond the margin of the fifth abdominal segment.

We have insufficient data upon the cremaster of Cuculliid pupæ for drawing definite conclusions therefrom, but the cremaster of intermedia certainly bears no resemblance to Copablepharon grandis in which latter species it appears to be identical with the type found in the commonest Agrotinæ, such as the numerous species of Euxoa. This consists of two stout terminal spines, which vary considerably as to form and divergence within the species, together with two supernumerary dorsal bristles, one or both of which may be absent.

The eggs of $C$. grandis are sub-globular. The upper surface is shallowly rugose, and the under side is smooth. In captivity they were laid in the soil, and were greenish-white when deposited.

With the exception of the spined tibix the adults, which have long narrow primaries, show greater affinities to the Cuculliinæ than they do to the Agrotinæ. From the appearance and habits of the larvæ, and from the pupal cremaster, however, it would seem that this genus is rightly placed in the latter sub-family despite the superficial resemblance of the pupa and adult to those of some genera in the Cuculliinæ.

\section{Literature Cited.}

1917. Barnes and McDunnough. Check list of the Lepidoptera of Boreal America.

1903-10. Hampson. Catalogue of the Lepidoptera Phalanæ.

1874. Harvey. Buffalo Soc. Nat. Sci. Bull. 11, p. 275.

1878. Harvey. Can. Entom., Vol. 10, p. 57. 
1843. Humphreys. British Moths, Vol. I.

1869. Lintner. 23rd Rep. State Cabinet of New York, p. 214. 1916. Mosher. Bull. Illinois State Lab. of Nat. Hist., Vol. XII, Art. II.

\section{AN INSECT AND LACK OF ENTOMOLOGICAL KNOWLEDGE AN IMMEDIATE CAUSE OF THE WORLD WAR.}

By M. T. Smulyan,

U. S. Bureau of Entomology, Melrose Highlands, Mass.

"What dire offence from amorous causes springs, What mighty contests rise from trivial things!"

-Pope.

Those familiar with the beliefs of the ancient Greeks doubtless recall the highly fascinating bit of tradition dealing with Peleus and Thetis and the events which grew out of their marriage; how Peleus, King of Thessaly, wooed and finally overcame the scruples of the divine Thetis; how that mortal, in order to please his bride, invited the gods of Olympus to attend the nuptial rites and festivities on Mount Pelion; how the vindictive Discordia, previously expelled from heaven for sowing dissension and stirring up strife, in revenge, for not having been included among those invited, threw an apple in their midst, with the inscription, "To the most beautiful"; how this aroused the envy and jealousy of the proud and powerful divinities, Juno, Venus, and Minerva; how the dispute was carried for arbitrament to the shepherd Paris, son of Priam, King of Troy; how Paris decided in favor of Venus who offered the most tempting bribe, that of the fairest woman as wife; how later, with the assistance of the goddess, he contrived to visit the court of Menelaus, King of Sparta, husband of Helen; how the base prince then, violating all laws of hospitality and honor, carried the beautiful Helen away to Troy; and, finally, how all Greece rose to avenge the insult and the wrong.

Thus did a mere apple cause that mighty commotion, the Trojan War.

Historians and others interested in tracing the cause and origin of the late war, the great human convulsion of modern times, 

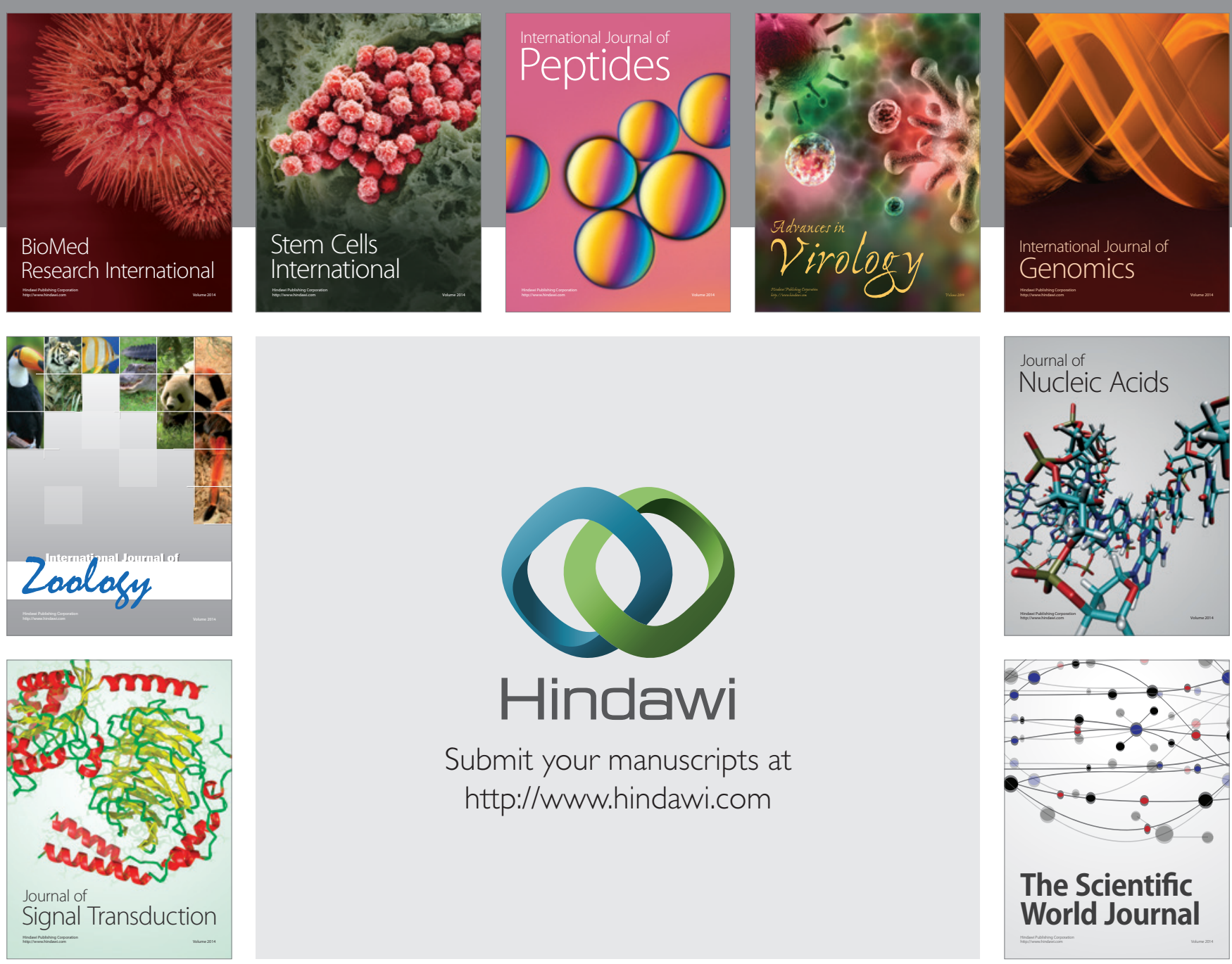

Submit your manuscripts at

http://www.hindawi.com
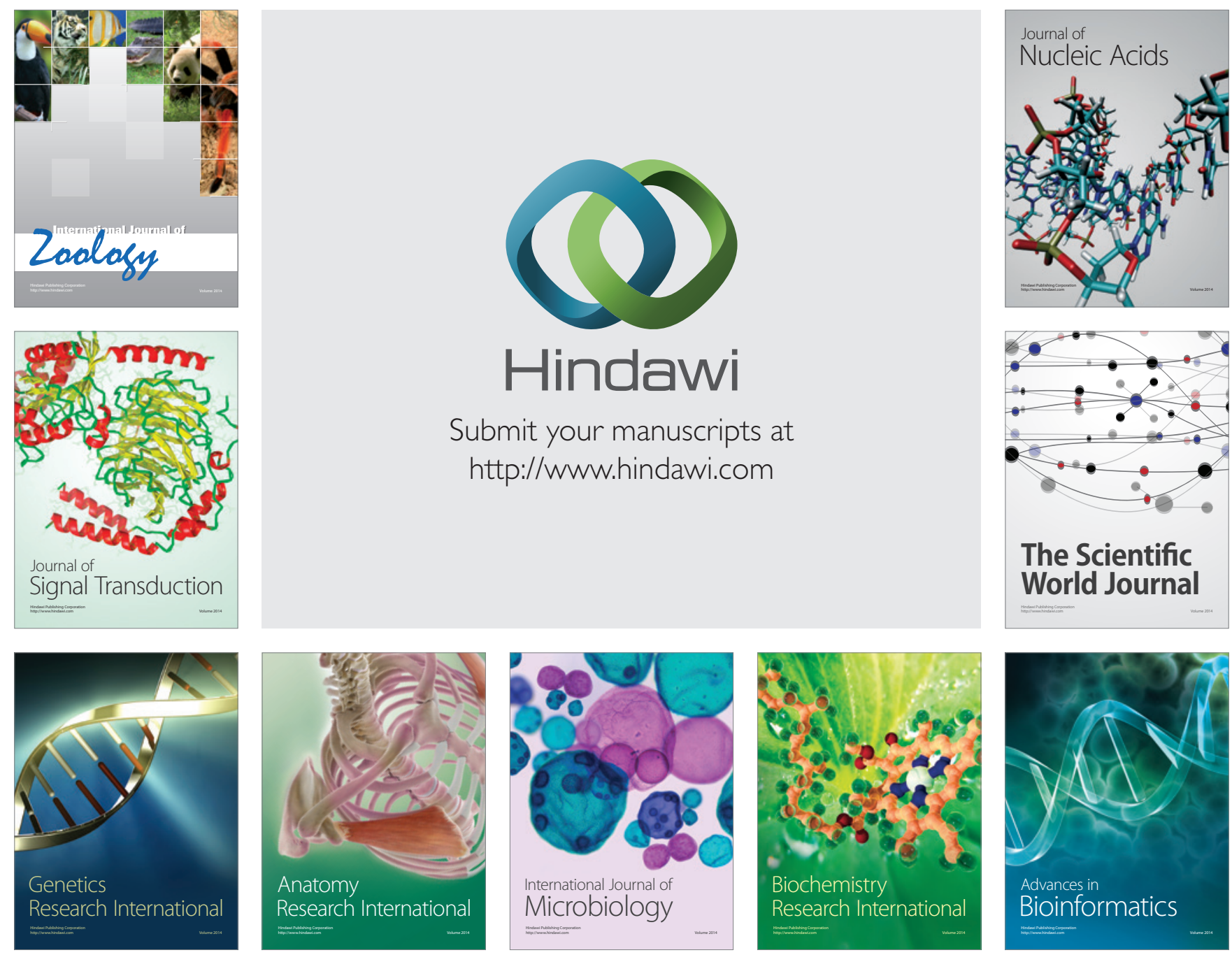

The Scientific World Journal
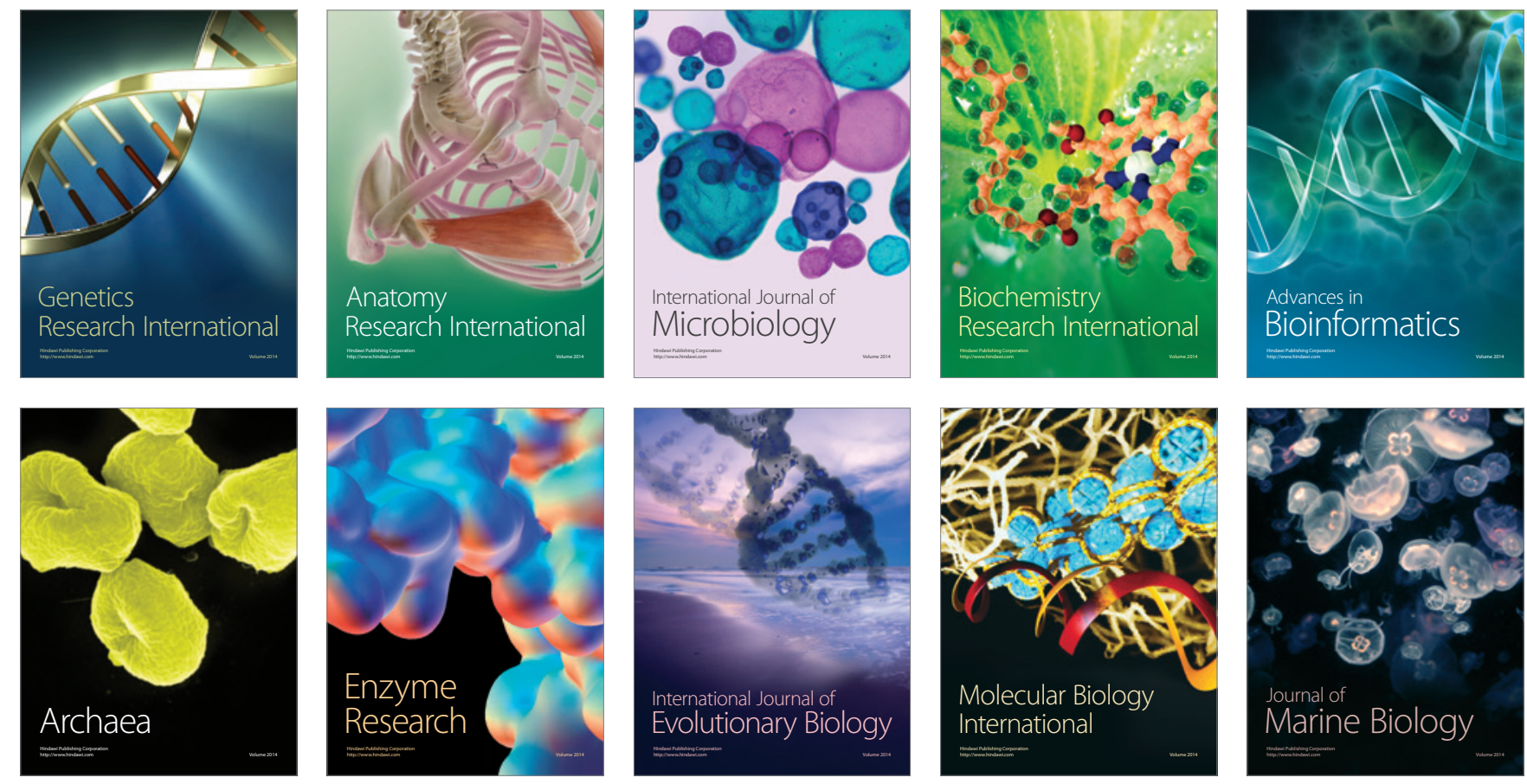